NBER WORKING PAPER SERIES

\title{
THE STATE OF CORPORATE GOVERNANCE RESEARCH
}

\author{
Lucian A. Bebchuk \\ Michael S. Weisbach \\ Working Paper 15537 \\ http://www.nber.org/papers/w15537
}

\section{NATIONAL BUREAU OF ECONOMIC RESEARCH \\ 1050 Massachusetts Avenue \\ Cambridge, MA 02138}

November 2009

We would like to thank Léa Stern for her diligent help in preparing this paper. The views expressed herein are those of the author(s) and do not necessarily reflect the views of the National Bureau of Economic Research.

NBER working papers are circulated for discussion and comment purposes. They have not been peerreviewed or been subject to the review by the NBER Board of Directors that accompanies official NBER publications.

(C) 2009 by Lucian A. Bebchuk and Michael S. Weisbach. All rights reserved. Short sections of text, not to exceed two paragraphs, may be quoted without explicit permission provided that full credit, including (c) notice, is given to the source. 
The State of Corporate Governance Research

Lucian A. Bebchuk and Michael S. Weisbach

NBER Working Paper No. 15537

November 2009

JEL No. G34

\begin{abstract}
$\underline{\text { ABSTRACT }}$
This paper, which introduces the special issue on corporate governance co-sponsored by the Review of Financial Studies and the National Bureau of Economic Research (NBER), reviews and comments on the state of corporate governance research. The special issue features seven papers on corporate governance that were presented in a meeting of the NBER's corporate governance project. Each of the papers represents state-of-the-art research in an important area of corporate governance research. For each of these areas, we discuss the importance of the area and the questions it focuses on, how the paper in the special issue makes a significant contribution to this area, and what we do and do not know about the area. We discuss in turn work on shareholders and shareholder activism, directors, executives and their compensation, controlling shareholders, comparative corporate governance, cross-border investments in global capital markets, and the political economy of corporate governance.
\end{abstract}

\author{
Lucian A. Bebchuk \\ Harvard Law School \\ 1545 Massachusetts Avenue \\ Cambridge, MA 02138 \\ and NBER \\ bebchuk@law.harvard.edu \\ Michael S. Weisbach \\ Department of Finance \\ Fisher College of Business \\ Ohio State University \\ 2100 Neil Ave. \\ Columbus, $\mathrm{OH} 43210$ \\ and NBER \\ weisbach_2@fisher.osu.edu
}


This special issue of The Review of Financial Studies presents seven papers that were presented at a meeting of the corporate governance project of the National Bureau of Economic Research (NBER). The papers, which subsequent to the conference went through the usual review process of The Review of Financial Studies, represent cutting-edge research in important areas of corporate governance research. This special issue thus provides a good opportunity for taking stock of the state of corporate governance research in these areas.

Interest in corporate governance has been rapidly growing, both inside and outside academia, together with recognition of its importance. In the academic world, the interest in corporate governance has been truly interdisciplinary, with much work being undertaken by researchers not only from economics and finance but also from law, management, and accounting. The term "corporate governance" appears as a key word in the abstract of 987 papers over the past year on SSRN, and, given the huge amount of research being done in the area, SSRN in 2009 started the Corporate Governance Network (CGN) with 21 different subjectmatter electronic journals.

Shleifer and Vishny (1997) define corporate governance as referring to the way in which suppliers of finance assure themselves a return on their investment. Because returns to suppliers of finance depend on myriad legal and contractual arrangements, the operation of various markets, and the behavior of different types of players, corporate governance has evolved into various sub-literatures (e.g., Zingales, 1998; Becht, Bolton, and Röell, 2003; Hermalin, 2009).

Below we discuss in turn seven important areas of corporate governance research, each of which is represented by a paper in this special issue. For each of these areas, we discuss the importance of the area and the questions that it poses for researchers, how the paper in the special issue and other recent research advance our understanding of the area, and the questions 
that future research may do well to examine. Throughout, we stress questions concerning corporate governance that public and private decision-makers face; research that can shed light on these questions will have substantial implications and payoffs.

Section 1 focuses on shareholders and shareholder activism - the actions that shareholders may take to protect their interests. Section 2 focuses on corporate directors, while Section 3 turns to executives and their compensation. Whereas Section 1-3 focus on companies without a controlling shareholders, Section 4 considers companies with such shareholders. Sections 5 and 6 focus on international corporate governance, with Section 5 considering crosscountry comparisons and Section 6 discussing cross-border investments by foreign investors. Finally, Section 7 focuses on the political economy of corporate governance.

\section{Shareholders}

Berle and Means (1932) identified what appeared to be a fundamental contradiction in the corporate form of organization: While dispersed shareholders collectively have incentives to monitor the management of the firms for which they own stock, individually, the free-rider problem can ruin such incentives, leading to a lack of shareholder involvement in firms. Given that the distribution of stock ownership is important because of these free-riding considerations, Shleifer and Vishny (1986) pointed out that large percentage block shareholdings are more prevalent in the United States than previously thought (no one doubted their existence outside the U.S.). Morck, Shleifer, and Vishny (1988) and many follow-up studies have documented a robust empirical relation between these large shareholdings and corporate performance, holding in a wide variety of samples spanning a number of countries and time periods. 
The underlying reasons, however, for this relation between ownership structure and firm performance are not clear. The main explanation discussed in the Shleifer and Vishny (1986) article is through the possibility of hostile takeover, because such takeovers can be more profitable for a shareholder who already owns a large block of shares than for one who does not (see also Grossman and Hart, 1980). Yet, the empirical relation between ownership and performance appears to be too robust to be explained by hostile takeovers alone, since the same relation exists in countries and time periods in which there is no possibility of a hostile takeover.

Another possibility is that the relation could occur because of other actions taken by blockholders. Most shares of U.S. firms are held by informed, sophisticated institutional investors, many of whom have non-negligible stakes. And some outside shareholders pursue active and sometimes aggressive strategies - proxy fights and takeover bids in the past, and hedge fund activism in the past decade.

Financial economists have accordingly been increasingly looking at the effects of shareholder actions. There have been a number of studies that have examined the effect of public pension funds and other institutional investors on the firms in which they invest [see Del Guercio and Hawkins (1999), Gillan and Starks (2000), Hartzell and Starks (2003), as well as Karpoff (2001) and Gillan and Starks (2007) for surveys]. In recent years, the most important players in the activism landscape have been activist hedge funds. The activities and payoffs of such hedge funds, which are willing to make substantial investments in engagement with companies, are the subject of recent studies by Brav, Jiang, Thomas, and Partnoy (2008), Greenwood and Schor (2009), and Klein and Zur (2009).

One key question on which research has focused is the effect of activism on profitability Are activists producing value for firms and their fellow shareholders? Or are they hurting their 
fellow shareholders? Such questions have been asked in the past about shareholders mounting proxy fights and takeover bids and have been more recently asked about hedge fund activists. The resolution of these questions has important policy implications for debates on the optimal scope of shareholder rights in public companies (e.g., Bebchuk, 2005, 2007; Bainbridge, 2006; Strine, 2006; Lipton and Savitt, 2007). Whereas a conclusion that activism is beneficial provides support for strengthening shareholder rights, the opposite conclusion provides support for constraining them.

Unlike activist shareholders who mounted proxy fights and takeover bids in the past, the activist hedge funds that attracted the limelight in the past decade do not commonly seek to acquire the company themselves. Instead they try to affect the way in which the company is run or to get the company to be acquired by someone else. Importantly, they most commonly contact companies privately, so it is difficult to gauge the magnitude of their intervention using publiclyavailable data. It also is not clear what the net effect of institutional activism is. Are activists producing a collective good, which is still under-provided and whose actions should be encouraged? Or are they destroying value at the expense of other investors? [see Kahan and Rock (2007) for a survey and discussion of this issue].

Unfortunately, informal contact between institutional investors and firms is by its nature private and difficult to quantify. Consequently, there has historically been only one study of such activism: Carleton, Nelson, and Weisbach (1998) gather a sample of letters between TIAACREF (a large U.S. pension fund) and companies. They find that TIAA-CREF typically does not ask firms to make large operational changes but are usually successful at inducing firms to make the relatively small changes they ask for (such as having a shareholder vote before adopting 'Blank-Check Preferred Stock,' or having women or minority representatives on their board of 
directors). Yet, it is impossible to know exactly how representative TIAA-CREF is of other U.S. (or international) institutions in terms of its activism.

Becht, Franks, Mayer, and Rossi (2009), a study included in this special issue, utilizes privately obtained data from Hermes, the fund manager owned by the British Telecom Pension Scheme, on engagements with management in companies targeted by its U.K. Focus Fund (HUKFF) between 1998 and 2004. This fund has been highly involved with activism and also has been unusually successful, earning abnormal annual returns net of fees of $4.9 \%$. Becht,Franks, Mayer, and Rossi have complete access to the records of all activism by Hermes, including private interventions that would be unobservable in studies purely relying on public information. Becht, Franks, Mayer, and Rossi document the way in which Hermes frequently seeks and achieves significant changes in the company's strategy, including refocusing on the core business and returning cash to shareholders, as well as changes in the executive management such as the replacement of the CEO or chairman. These authors estimate that around $90 \%$ of the abnormal fund returns is due to the activism program.

Becht, Franks, Mayer, and Rossi (2009) is a significant study because it provides a window into the nature of 'behind the scenes' activism and shows that such activism can be important. The study suggests that financial institutions can increase in value not just by buying and selling securities strategically, but also by creating value inside of firms by providing monitoring services. It provides an example of the way in which it is possible to learn a great deal from the details of the actions of a single (particularly interesting) financial institution.

There are some questions that future research should try to address. If activism produces such large returns, why has Hermes not done it on a larger scale? Is the ability to produce such results unique to Hermes or a few such players or is it something that has been done, or can be 
done, by other U.K. players with similar success? Note also that the large returns that the study shows raise the question of why more capital does not flow into this work, reducing returns, and in the process also possibly reducing slack in the economy. We need to understand better what the barriers are to entry if any into activism. Interestingly, large returns from activism do not indicate that a system is working well. The fact that activism can generate such large returns might indicate that a high level of slack exists prior to activist intervention.

It will also be important to understand the extent to which the findings are due to the particular legal and institutional features of the U.K. system. As Becht, Franks, Mayer, and Rossi (2009) note, legal rules in the U.K. give shareholders much more power than U.S. shareholders have. Understanding the ways in which the payoffs and effects of activism depend on legal rules is an important question for financial economists to investigate.

The financial crisis has intensified the ongoing debate about the role that shareholders should play in corporate governance. To some, increasing shareholder power and facilitating shareholder intervention when necessary is part of the necessary reforms. To others, activism by shareholders who potentially have short-term interests is part of the problem, not a solution. To what extent (and when) can shareholder activism improve firm value and performance? To what extent (and when) can shareholder activism produce distortions that make matters worse? Research by financial economists that seeks further light on these questions will provide valuable input to the questions with which decision-makers are wrestling.

\section{Boards of Directors}

An alternative to direct monitoring by shareholders is governance through the board of directors, who are elected by shareholders. Yet, as has been recognized at least since Smith (1776) and 
Berle and Means (1932), directors' interests may not fully overlap with those of shareholders. The complex three-way relationship among shareholders, boards, and top management has been the subject of a large literature [see Hermalin and Weisbach (2003) and Adams, Hermalin, and Weisbach (2009) for surveys].

How do we make boards work better? One recipe that has been increasingly suggested by public and private decision-makers is to have independent boards [see Gordon (2007) on the rise of independent directors]. Indeed, a common policy response to observed 'governance crises' has been to adopt reforms designed to strengthen the independence of boards. For example, following the Enron and WorldCom scandals in 2002, the exchanges increased independence requirements, and the Sarbanes-Oxley Act of 2002 required the independence of audit committees. The financial crisis has similarly led to the consideration of legislation aimed at bolstering the independence of compensation committees.

Why impose regulatory limits on the composition of the board? Hermalin and Weisbach (1998) present a model in which directors imposed on the firm by regulations are likely to be less effective than those picked through the endogenous selection process that would occur in the absence of regulation. At the same time, regulators are typically concerned that, without regulation, opportunism by insiders might lead to insufficient independence of directors.

Nonetheless, given the growing importance of independent directors, whether due to regulation or to choices made by firms, it is important to study empirically the effects of director independence. Initial work on the subject failed to find a link between board independence and higher firm value (Hermalin and Weisbach, 1991; Bhagat and Black, 1999, 2002). However, there is a growing body of empirical research indicating that director independence is associated with improved decisions with respect to some specific types of decisions (e.g., Byrd and 
Hickman, 1992; Shivdasani, 1993; Brickley, Coles, and Terry, 1994; Cotter, Shivdasani, and Zenner, 1997; Dann, Del Guercio, and Partch, 2003; Gillette, Noe, and Rebello, 2003). In particular, it has been shown that director independence has an impact on CEO turnover (e.g., Weisbach, 1988), executive compensation decisions (e.g., Core, Holthausen, and Larcker, 1999; Chhaochharia and Grinstein, 2008), the incidence of fraud (e.g., Beasley, 1996; Dechow, Sloan, and Sweeney, 1996; Beasley, Carcello, Hermanson, and Lapides, 2000), and on the incidence of opportunistic timing of stock option grants (e.g., Bebchuk, Grinstein, and Peyer, 2009). ${ }^{1}$

An important, and necessary, condition for directors to be able to be effective is the amount and nature of information that they have. If directors only have access to publiclyavailable information, it is hard to imagine that they will be able to evaluate management better than an outside shareholder. In addition, the mere fact that directors do not have superior information would in itself likely be the consequence of a strained relationship with management, since presumably no information of value would have been transmitted during board meetings. The informational advantage of directors over outsiders thus presumably provides a measure of the potential for these directors to add value.

Ravina and Sapienza (2009), in this special issue, adopt a novel strategy to estimate the magnitude of this informational advantage. These authors compare the trading performance of independent directors and other officers of the firm. Their interesting finding is that independent directors earn positive and substantial abnormal returns when they purchase their company stock and that the difference with the same firm's officers' personal trading returns is relatively small at most horizons. Executive officers and independent directors both earn higher returns in firms with the weakest governance. In addition, independent directors who sit on the audit committee

\footnotetext{
${ }^{1}$ Recent work (Chhaochharia and Grinstein, 2006) also documents that reforms requiring some firms to increase their use of independent directors were associated with increases in the firm value of such firms.
} 
earn higher returns than other independent directors at the same firm. Finally, independent directors earn significantly higher returns than the market when they sell the company stock in a window before bad news and around earnings restatements. The authors view their results as consistent with the view that independent directors have an informational advantage over outsiders and thus can perform their job well.

While Ravina and Sapienza (2009) stress the implications of their findings for the ability of independent directors to perform their role well, one could also draw inferences from it concerning their incentives to do so. In particular, to the extent that independent directors rely on management for the receipt of information, independent directors who made larger trading profits might have been individuals that were close to management or whose performance of the oversight function might have been more favorable to management. Bebchuk, Grinstein, and Peyer (2009) find that independent directors have been recipients of opportunistically timed stock option grants, and they show that the directors' benefits from such lucky timing were associated with substantial benefits to the CEO. In particular, they find that, for any given firm and CEO, the odds of a CEO grant being lucky were significantly higher when the independent directors of the firm received grants on the same date; and that director grant events not coinciding with awards to executives were more likely to be lucky when the CEO received a lucky grant in the same or prior year.

The Ravina and Sapienza (2009) study, and the other recent works discussed in this section, highlight the value of the work by financial economists on independent directors, who play a major role in corporate decision-making. Financial economists should not generally assume that independent directors seek to maximize shareholder value; rather, the decisions of independent directors, like those of other economic agents, might well be influenced by their 
incentives, which in turn are a product of various features of the environment in which they operate. The information that independent directors have should be similarly recognized to be endogenously determined by corporate structures and processes, rather than to be exogenously given. Additional work on the incentives and information of independent directors would be worthwhile.

\section{Executive Compensation}

In the ordinary course of events, public firms are managed by executives, not directors or shareholders. Executives' decisions are influenced by the directors' oversight, as well as by shareholders' monitoring. Executives' decisions are also affected, however, by the incentives provided to them by their executive compensation arrangements. These compensation arrangements have become the subject of a large literature [see Murphy (1999) and Core, Guay, and Larcker (2003) for surveys].

There are at least two views of executive compensation in the literature. One view ("the optimal contracting view") sees executive pay arrangements as the product of arm's length contracting between boards and executives, which leads to contracts that provide efficient incentives for reducing agency problems as much as possible (e.g., Holmstrom, 1979). An alternative view ("the managerial power view") questions whether pay arrangements are the product of arm's length contracting and sees such pay arrangements as part of the agency problem itself rather than as a solution to it (Bebchuk and Fried, 2003, 2004).

One part of the debate on executive compensation concerns compensation levels (Kaplan 2008). Are the levels of executive compensation, which have grown considerably relative to rank-and-file compensation in recent years (Jensen, Murphy, and Wruck, 2004; Bebchuk and 
Grinstein, 2005), a reflection of supply and demand in the labor market for executives? Or do they reflect rent-seeking by powerful managers? Given the attention that pay levels receive from the media, the public, and policy-makers, a better understanding of the factors affecting them is clearly an important research topic.

The second dimension to the debate concerns the structure of pay arrangements. Under the optimal contracting view, the design of pay arrangements is presumed to be (second-best) efficient. In contrast, the managerial power view allows for the possibility that pay arrangements will be structured sub-optimally in ways that lead to diluted or even perverse incentives. While Jensen and Murphy (1990) argued that pay is insufficiently tied to performance due to outside social pressures, the managerial power view suggests that sub-optimal pay-performance sensitivity could itself be a product of executive influence. To financial economists, the question of incentives, and in particular the extent to which incentives provided by pay arrangements should be presumed to be optimal, is of significant importance.

Some recent work by financial economists, including the work by Kaplan and Rauh (2009) in this special issue, seeks to explain the growth of executive pay within the arm's length contracting paradigm by suggesting that it reflects an increase in the value of executives' marginal contributions and improvements in their outside options. Murphy and Zabojnik (2007) suggest that the growth in pay reflects a shift in the importance of "managerial ability" (skills transferable across companies) relative to "firm-specific human capital" (valuable only within the organization), which operated to strengthen executives' bargaining position by improving their outside options. Gabaix and Landier (2008) develop a model in which the marginal product of an executive of a given quality is proportional to the market capitalization of the firm, and argue that the growth of pay has been due to the increase in the market capitalization of firms. The 
extent to which these theories can explain the time-series variation in executive compensation is questioned on empirical grounds by Dew-Becker and Gordon (2007), Cremers and Grinstein (2009), and Frydman and Saks (2009).

Kaplan and Rauh (2009) examine the question of whether the growth of pay can reflect market forces in a creative way. The idea is that if executive pay reflects market forces, then its growth should parallel that of other high paid professions. Kaplan and Rauh gather data on compensation from high paying fields such as financial service sector employees from investment banks, hedge funds, private equity funds, and mutual funds (Wall Street), as well as corporate lawyers, professional athletes, and celebrities.

The estimates of Kaplan and Rauh (2009) lead them to conclude that non-financial public company CEOs and top executives do not represent more than $6.5 \%$ of any of the top AGI brackets (the top $0.1 \%, 0.01 \%, 0.001 \%$, and $0.0001 \%$ ). Individuals in the Wall Street category comprise at least as high a percentage of the top AGI brackets as non-financial executives of public companies. Kaplan and Rauh argue that this evidence suggests that the growth of executive pay is not reflective of suboptimal contracting, but rather is most consistent with theories of superstars, skill biased technological change, greater scale, and the interaction of these effects.

Although Kaplan and Rauh (2009) suggest that the growth of pay levels could be consistent with the optimal contracting view, they do not attempt to test directly whether compensation is indeed the product of arm's length contracting. A full defense of this view would have to address the empirical evidence that compensation levels are higher (as well as less sensitive to performance) when governance is weaker [see Bebchuk and Fried (2004, Chapter 6) for a survey]. Among other things, there is evidence that CEO pay is higher when outside 
directors serve on multiple boards, when the board has interlocking directors, when more of the outside directors have been appointed under this CEO, when there are no large outside blockholders, when a smaller percentage of shares is held by institutional investors, and when antitakeover protections are more significant (e.g., Borokhovich, Brunarski, and Parrino, 1997; Hallock, 1997; Core, Holthausen, and Larcker, 1999; Cyert, Kang, and Kumar, 2002; Hartzell and Starks, 2003). ${ }^{2}$

Whereas Kaplan and Rauh (2009) defends the optimal contracting view against claims that pay levels have been excessive, some other recent work seeks to defend this view against claims that compensation structures have been inefficiently designed.. In particular, Edmans, Gabaix, and Landier (2009) present a model in which optimal pay lines up closely with empirical observations on actual executive compensation. And while many public officials expressed concerns that standard pay arrangements provide excessive incentives to focus on the short-term [an argument stressed in Bebchuk and Fried (2004, Chapter 14)], Fahlenbrach and Stulz (2009) argue that there is no empirical evidence that such incentives have played a role in the run-up to the financial crisis.

Although interest in executive pay has been high for quite some time, the Financial Crisis of 2008-2009 has further intensified this interest. Public attention to the compensation levels of top officials appears to be at an all-time high. Regulators around the world are examining measures to improve the structure of compensation, and not to make things worse through ill thought out provisions. And authorities in the U.S. and elsewhere are considering measures to improve the corporate governance processes that produce pay arrangements. The examination of

\footnotetext{
${ }^{2}$ There is also evidence that weaker corporate governance is associated with lower sensitivity of pay to performance (Bertrand and Mullainathan, 2001) and opportunistic compensation practices such as those manifested by option backdating (Bebchuk, Grinstein, and Peyer, 2009; Bizjak, Whitby, and Lemmon, 2009).
} 
pay arrangements and the pay-setting processes by public and private decision-makers, we hope, will be informed from the ongoing and future research of financial economists.

\section{Controlling Shareholders}

The nature of governance problems differs greatly between public companies with and without a controlling shareholder (La Porta, Lopez-de-Silanes, and Shleifer, 1999; Bebchuk and Hamdani, 2009). With controlling shareholders, the market for corporate control that plays such an important role in the analysis of companies without a controller, cannot provide a source of discipline. With a controlling shareholder, the fundamental governance problem is not opportunism by executives and directors at the expense of public shareholders at large but rather opportunism by the controlling shareholder at the expense of the minority shareholders.

The Becht, Franks, Mayer, and Rossi, Ravina and Sapienza, and Kaplan and Rauh papers in this issue all focus on companies without a controlling shareholder - the common structure among publicly traded firms in the U.S. and the U.K. and the one on which most research has focused. But as the work on comparative corporate governance has shown (Becht and Röell, 1999; La Porta, Lopez-de-Silanes, and Shleifer, 1999; Franks and Mayer, 2001), companies with a controlling shareholder are the dominant form among publicly traded firms in most countries. Holderness (2009) shows that controlling shareholders are more common even in the U.S. than is usually assumed.

One important type of controlling shareholders are those labeled "controlling minority shareholders" by Bebchuk, Kraakman, and Triantis (2000). These are shareholders who own only a minority (and sometimes a small minority) of the company's cash flow rights but control a majority of the votes and thus have a lock on control. An owner of minority of the cash flow 
rights can control a majority of the votes when cash flow rights and votes are separated due to the use of dual-class stock, corporate pyramids, or cross-holdings. Such structures are quite common in many countries (Claessens, Djankov, and Lang, 2000; Faccio and Lang, 2002). Bebchuk, Kraakman, and Triantis (2000) show that such structures have the potential to create very large agency costs that are an order of magnitude larger than those associated with controlling shareholders who hold a majority of the cash flow rights in their companies. Bertrand, Mehta, and Mullainathan (2002) present evidence about the significant amount of tunneling that takes place in such firms.

In the U.S., controlling minority shareholder structures commonly occur through the use of dual-class shares. In such firms, multiple classes of stocks will trade, typically with the same dividend rights but different voting rights. This arrangement ensures that control is kept in the hands of a small group of individuals, usually the founder and/or his family, even though the company can be traded publicly with many shareholders. The wedge between the prices of the different classes of stock reflects the private benefits of control enjoyed by the high-vote shareholders. There have been a number of papers documenting the patterns of ownership, the prices of dual class stocks, and the value of voting rights in such firms both in the U.S. and internationally (e.g., Zingales, 1994, 1995; Nenova, 2003). Yet, these studies have typically had relatively small samples that limit their ability to answer important questions about dual class firms, such as the incremental effect of dual class ownership on valuation.

Gompers, Ishii, and Metrick (2009), in this issue, consider the issue of governance when cash flow rights and voting rights are separated. They assemble a comprehensive list of dualclass firms in the U.S. and use this list to investigate the relationship between insider ownership and firm value. Their data (which is available at the Review of Financial Studies website) has 
two useful features for this valuation analysis. First, since dual-class stock separates cash-flow rights from voting rights, they can separately identify the impact of each. Second, they address endogeneity concerns by using exogenous predictors of dual-class status as instruments.

In single-stage regressions, Gompers, Ishii, and Metrick (2009) find strong evidence that firm value is increasing in insiders' cash-flow rights and decreasing in insider voting rights. In instrumental-variable regressions, the point estimates remain the same sign and magnitude, but the significance levels are lower. This work illustrates the importance of ownership structure for valuation. Because of its instrumental variable approach, it has a relatively clean way of measuring the impact of controlling shareholders that can appropriate private benefits from minority ones.

The Gompers, Ishii and Metrick (2009) paper thus makes a contribution to the accumulating empirical evidence that controlling minority shareholder structures are associated with increased agency costs and reduced firm value. The question then arises why such structures develop and are maintained, and what should be the public policy toward them. Given the importance of companies with controlling minority shareholders in many countries around the world, these questions should be part of the research agenda of financial economists.

\section{International Comparisons}

Until the mid-1990s, most of the work on corporate governance has been in the context of U.S. firms. But the influential work of La Porta, Lopez-de-Silanes, and Shleifer (1999) and La Porta, Lopez-de-Silanes, Shleifer, and Vishny (1997, 1998, 2000a, 2000b, 2002) has stimulated a large body of work on international comparisons [see Levine (2005) and La Porta, Lopez-de-Silanes, and Shleifer (2008) for surveys]. 
Much of this work has focused on differences between countries' legal systems (including their systems of enforcement), and has studied how such differences relate to differences in how economies and capital markets perform. La Porta, Lopez-de-Silanes, Shleifer, and Vishny $(1997,1998)$ put forward an anti-director index for measuring the legal protection accorded to investors, and this index has been subsequently used by more than one hundred studies (Spamann, 2009). How best to measure the extent to which a particular country's legal system protects the rights of public investors is an active area of research in which recent work seeks to provide improved indices for this purpose (Hail and Leuz, 2006; Djankov, La Porta, Lopez-de-Silanes, and Shleifer, 2008; Jackson and Roe, 2008).

While research on comparative corporate governance has in the past mainly focused on cross-country differences in governance, a substantial body of research about U.S. firms has been showing that cross-firm differences in governance have substantial effect on firm value and performance. Gompers, Ishii, and Metrick (2003) have shown that a governance index (the Gindex) based on 24 provisions is negatively correlated with firm value. Bebchuk, Cohen, and Ferrell (2009) point out that six of these provisions fully drive the Gompers-Ishii-Metrick results and propose an alternative entrenchment index based on them (the E-index). A particularly important component of the G-index and the E-index is whether boards are staggered (Bebchuk, Coates, and Subramanian, 2002; Bebchuk and Cohen, 2005). A significant number of subsequent studies have identified many ways in which the G-index, the E-index, and the existence of staggered boards are associated with firm performance and behavior (e.g., Masulis, Wang, and Xie, 2007; Kedia and Philippon, 2008).

Given the magnitude of firm-level differences in governance, it is a natural next step for the literature on international comparisons to try to look beyond cross-country and incorporate 
into the investigation firm-level differences. Aggarwal, Erel, Stulz, and Williamson (2009), in this issue, take this step using a new database of firm-level governance provisions put together by RiskMetrics, a global shareholder advisory firm. ${ }^{3}$ Bruno and Claessens (2007) and Chhaochharia and Laeven (2007) also use this dataset to investigate the subject.

With data on both country-level and firm-level governance, an important question investigated by Aggarwal, Erel, Stulz, and Williamson (2009) is how these two types of governance choices interact. Does having a good legal system act as a substitute for firm-level choices? Or does it facilitate firm-level governance, making the two types of governance complements? Theoretically, either is possible, so the question can only be answered by examining data on firm and country level governance.

Given that the U.S. is known for its high economic development and strong investor protection, the authors examine whether comparable non-U.S. firms choose higher or lower levels of protection than similar U.S. firms. They construct a firm-level governance index that increases with minority shareholder protection. Compared to U.S. matching firms, only $12.68 \%$ of foreign firms have a higher index. The value of foreign firms falls as their index decreases relative to the index of matching U.S. firms, implying that the governance attributes examined in the study are relevant for shareholder value. The authors view these findings as consistent with the "complements" view under which lower country-level investor protection make it suboptimal for foreign firms to invest as much in governance as U.S. firms do.

As done by Aggarwal, Erel, Stulz, and Williamson (2009), future research on comparative corporate governance should strive to take firm-level governance into account. The use of the RiskMetrics dataset for this purpose, however, has some limitations. Bebchuk and

\footnotetext{
${ }^{3}$ At the time of the study, the database was owned by I.S.S. and is consequently referred to as the I.S.S. database by Aggarwal, Erel, Stulz, and Williamson (and other authors).
} 
Hamdani (2009) point out that the RiskMetrics dataset is U.S.-centric in that it focuses on features that are important for the companies without controlling shareholder that are dominant in the U.S. capital market but not in most other capital markets around the world. Indeed, the finding of Aggarwal, Erel, Stulz, and Williamson (2009) that firm-level governance is better in U.S. firms than in firms from other countries is likely to be at least partially due to the U.S.centric nature of the dataset used by this study.

The Bebchuk and Hamdani (2009) analysis suggests a direction that would be worth

pursuing by work on international comparisons. Much of the work thus far has sought to develop and employ a single global governance standard for making either country-level or firm-level comparisons around the world. However, governance arrangements that are optimal for investor protection in companies without a controlling shareholder could be suboptimal for companies with such a controller, and vice versa. Consequently, the quest for a single global governance standard should be replaced with separate standards for evaluating governance in firms with and without a controlling shareholder. The development and application of such standards is potentially an important task for future research.

\section{Cross-Border Investing}

A substantial part of the work on international comparisons abstracts from the movement of firms and capital across borders. It takes as given that each country has a given set of firms and a given amount of capital invested in these firms, and it focuses on how firms in different countries vary in how they are governed. In our increasingly globalized world, however, there is in fact much movement across borders, and there is some research that seeks to understand the causes and consequences of such movement. 
One important element of cross-border movements concerns decisions by firms headquartered and operating in a given country to subject themselves to the governance rules of other countries. Coffee (1999) and Stulz (1999) have suggested that firms can therefore "bond" themselves to good governance by incorporating in another country or by listing on a foreign exchange. There is a significant line of work examining why firms "migrate" to foreign governance systems and the extent to which such migration is due to a desire by firms to "bond" themselves to governance arrangements that provide tighter protection to public investors (Reese and Weisbach, 2002; Pagano, Röell, and Zechner, 2002; Doidge, Karolyi, and Stulz, 2004; Siegel, 2005; Doidge, Karolyi, Lins, Stulz, and Miller, 2009). ${ }^{4}$

Another important element of global capital markets is cross-border movement of capital. In contrast to classical portfolio theory, investors tend to have a "home bias" in favor of investing in firms of the investor's country of residence. Recently, however, investors have been increasingly allocating part of their equity investments to foreign companies. As it is natural to ask how the migration of firms across borders is influenced by governance considerations, it is also natural to ask how cross-border investing flows are influenced by such considerations.

The level of investor protection is likely to be particularly important for investors considering purchasing securities issued by a company from another country. Foreign investors tend to have less information about companies they invest in than domestic investors and also tend to have fewer political connections, or long-term relationships with the firm that can potentially substitute for governance. Under this hypothesis, the quality of governance in a firm should be correlated with the foreign stockholders in a company. In particular, since strong

\footnotetext{
${ }^{4}$ This work is naturally related to the substantial literature on regulatory competition among states seeking to attract incorporations (Romano, 1985; Bebchuk, 1992; Romano, 1997; Daines, 2001; Bebchuk and Hamdani, 2002; Bebchuk and Cohen, 2003; Kahan, 2006; Bar-Gill, Barzuza, and Bebchuk, 2006).
} 
governance makes a firm relatively more attractive to foreigners than to domestic investors, foreigners should have a higher percentage ownership in firms where investors are better protected.

The study by Leuz, Lins, and Warnock (2009), in this issue, tests this hypothesis. There has been much work documenting that increased disclosure makes a firm more attractive to all investors [see Hermalin and Weisbach (2009) and the references therein], and Leuz, Lins, and Warnock show that such openness is particularly important in attracting foreign investors. The authors study 4,409 firms from 29 countries to assess whether and why concerns about corporate governance result in fewer foreign holdings. Their results suggest that foreigners invest less in firms that reside in countries with poor outsider protection and disclosure and have ownership structures that are conducive to governance problems. This effect is particularly pronounced when earnings are opaque, indicating that the information asymmetry and monitoring costs faced by foreign investors likely drive the results.

The findings of Leuz, Lins, and Warnock (2009) confirm that governance problems impede firms' ability to attract capital from foreign investors even more than it impedes their ability to raise capital domestically. Poor governance can thus limit capital flows and the integration of capital markets in the global economy. These findings are especially important given that some of the countries whose investor protection is especially weak are also those countries for whom capital investment from abroad is especially significant. Thus, governance reforms in such countries might produce considerable benefits for their economies. Whether such reforms will in fact occur depends in part on the political economy of governance reforms, which is the subject of the next section. 


\section{Politics}

Corporate governance is in part a product of legal systems put in place and the legal infrastructure accompanying them. And throughout the earlier discussion we have talked about the potential significance of differences among systems of corporate governance in different countries. Such systems differ considerably around the world and, for any given country, over time.

There is a lot of research that either takes the legal rules as given and examines how agents make choices given them, or asks what legal arrangements are desirable assuming that public officials generally seek to adopt whatever rules are optimal. But why then would countries that are in a similar stage of their economic development have legal rules that are so different and why do so many countries persist in having systems that seem to provide patently insufficient legal protection to public investors?

One important strand seeks to relate cross-country differences to some innate, longstanding differences among countries. This line of work suggests that a country's level of investor protection may be influenced by long-standing factors such as the country's legal origin (La Porta, Lopez-de-Silanes, Shleifer, and Vishny, 1998; Glaeser and Shleifer, 2002; La Porta, Lopez-de-Silanes, and Shleifer, 2008), its culture and ideology (Bebchuk and Roe, 1999; Roe, 2003; Allen, 2005), or the religion of its population (Stulz and Williamson, 2003), all of which lie outside the realm of current political choices.

But given that countries do change their investor protection arrangements considerably over time, the level of such protection at any given point in time may also result at least partly from recent decisions by public officials. And the question is how these decisions are determined. The theory of regulatory capture (Stigler, 1971) suggests that the decisions by public 
officials might be influenced and sometimes distorted by the influence activities of rent-seeking interest groups. What can be said about the way in which interest group politics is played out in the area of corporate governance politics? In a recent Journal of Economic Literature survey, Morck, Wolfenzon, and Yeung (2005) stress the importance of developing formal political economy models of corporate governance arrangements and view this task as "a fascinating uncharted territory for creative theorists."

Bebchuk and Neeman (2009), in this issue, try to help fill this void and develop a formal political economy model of how lobbying by interest groups affects the level of investor protection. In their model, three groups - insiders in existing public companies, institutional investors (financial intermediaries), and entrepreneurs who plan to take companies public in the future - compete for influence over the politicians setting the level of investor protection. The authors identify conditions under which this lobbying game has an inefficiently low equilibrium level of investor protection.

Factors pushing investor protection below its efficient level include the ability of corporate insiders to use the corporate assets they control to influence politicians, and the inability of institutional investors to capture the full value that efficient investor protection would produce for outside investors. The interest that entrepreneurs (and existing public firms) have in raising equity capital in the future reduces but does not eliminate the distortions arising from insiders' interest in extracting rents from the capital that public firms already possess. The entrepreneurs prefer an efficient level of investor protection, and their introduction into the Bebchuk and Neeman (2009) model therefore moderates, but is shown not to eliminate, the bias in favor of excessive private benefits of control. While entrepreneurs do internalize the interests of those public investors who buy IPO shares when they take their firms public, they do not 
internalize, and neither does anyone else at the lobbying table, the interests of individuals who directly or indirectly hold shares in existing public firms and who are not at the table.

The essential point is that, in an economy with existing public firms, choices of investor protection levels affect not only the allocation of cash flows from the capital to be raised from public investors in the future but also the allocation of rents from the capital that public firms already have (Bebchuk and Roe, 1999). When those lobbying on behalf of insiders and outside shareholders do not fully internalize the costs and benefits of their choices on outside investors, the fight over these rents produces suboptimal investor protection levels even in the presence of entrepreneurs lobbying for efficient rules.

The insights generated by the Bebchuk and Neeman (2009) model complements those developed by Rajan and Zingales (2003, 2004) and Perotti and Volpin (2008), who argue that incumbent firms seeking to retain market power lobby for weak investor protection that would make it difficult for other firms to raise capital to enter. Bebchuk and Neeman focus on another conflict among interest groups — the struggle between public firms' corporate insiders, who seek to extract rent from the capital under their control, and the outside investors who provided them with capital. ${ }^{5}$

One important pattern established by the evidence is the positive correlation between high levels of investor protection and good economic outcomes such as well-developed stock

\footnotetext{
${ }^{5}$ Note that both the Bebchuk and Neeman (2009) and the Rajan, Zingales, Perotti, and Volpin (2009) line of work focus on lobbying by interest groups, in contrast to earlier work that has focused on how investor protection is shaped by the citizens' voting decisions and the preferences of the median voter (e.g., Pagano and Volpin ,2005a, 2005b; Perotti and Von-Thadden, 2006). Bebchuk and Neeman argue that, in the ordinary course of events, most corporate issues are intensely followed by the interest groups with sufficient stake and expertise but are not sufficiently understood and salient to most citizens. But they recognize that the ordinary pro-insider operation of interest group politics can sometimes be interrupted by pro-investor reforms resulting from corporate scandals or a stock market crash that makes voters more attentive to corporate governance problems, and they allow for this possibility in their model.
} 
markets and higher levels of economic growth (e.g., La Porta, Lopez-de-Silanes, Shleifer, and Vishny, 1998, 2000; La Porta, Lopez-de-Silanes, and Shleifer, 1999). One possible interpretation of this correlation is that higher levels of investor protection bring about such good economic outcomes. The results generated by the Bebchuk and Neeman (2009) model indicate, however, that some of the causality may go in the opposite direction: a high level of investor protection may be, at least partly, the product — rather than the cause — of high economic growth, a developed stock market, or an advanced-stage economy.

The model provides predictions relating differences in investor protection (both over time and around the world) to the structure of political and legal decision-making, the developmental stage of the economy, the corporate structures dominant in the economy, as well as to scandal waves and stock market crashes. While some of these results can help explain patterns identified by a number of existing empirical studies, it also provides new predictions that future empirical work may seek to test.

More generally, to improve the understanding of existing governance arrangements and how they could be improved, it is important for future work to take into account and study how such arrangements are influenced by interest group politics and how it can impede governance reforms. The framework offered by the Bebchuk and Neeman (2009) model might be helpful for such work.

\section{Conclusion}

This issue of The Review of Financial Studies contains seven papers that were presented in a meeting of the NBER's corporate governance project. Each of the papers makes a significant contribution to an important area of corporate governance. For each of these areas, we discuss its 
importance and current state of research, how the paper in this special issue makes a contribution, and some of the work that remains to be done. We hope that the papers in the special issue, and the additional work that will follow, will advance our understanding about these important areas. 


\section{References}

Adams, R., B. E. Hermalin, and M. S. Weisbach. The Role of Boards of Directors in Corporate Governance: A Conceptual Framework \& Survey. Journal of Economic Literature, forthcoming.

Aggarwal, R., I. Erel, R. M. Stulz, and R. Williamson. 2009. Differences in Governance Practices between U.S. and Foreign Firms: Measurement, Causes, and Consequences. Review of Financial Studies 2009: this issue.

Allen, F. 2005. Corporate Governance in Emerging Economies. Oxford Review of Economic Policy 21:164-77.

Bainbridge, S. 2006. Directory Primacy and Shareholder Disempowerment. Harvard Law Review 119:1735-49.

Bar-Gill, O., M. Barzuza, and L. A. Bebchuk. 2006. The Market for Corporate Law. Journal of Institutional and Theoretical Economics 162:134-71.

Beasley, M. S. 1996. An Empirical Analysis of the Relation between the Board of Director Composition and Financial Statement Fraud. Accounting Review 71:443-55.

Beasley, M., J. V. Carcello, D. R. Hermanson, and P. D. Lapides. 2000. Fraudulent Financial Reporting: Consideration of Industry Traits and Corporate Governance Mechanisms. Accounting Horizons 14:441-52.

Bebchuk, L. A. 1992. Federalism and the Corporation: The Desirable Limits on State Competition in Corporate Law. Harvard Law Review 105:1435-510.

Bebchuk, L. A. 2005. The Case for Increasing Shareholder Power. Harvard Law Review 118:833-917.

Bebchuk, L. A. 2007. The Myth of the Shareholder Franchise. Virginia Law Review 93:675-732.

Bebchuk, L. A., J. Coates, and G. Subramanian. 2002. The Powerful Antitakeover Force of Staggered Boards: Theory, Evidence \& Policy. Stanford Law Review 54:887-951.

Bebchuk, L. A., and A. Cohen. 2003. Firms' Decisions Where to Incorporate. Journal of Law and Economics 46:383-425. 
Bebchuk, L. A., and A. Cohen. 2005. The Costs of Entrenched Boards. Journal of Financial Economics 78:409-33.

Bebchuk, L. A., A. Cohen, and A. Ferrell. 2009. What Matters in Corporate Governance. Review of Financial Studies 22:783-827.

Bebchuk, L. A., and J. Fried. 2003. Executive Compensation as an Agency Problem. Journal of Economic Perspectives 17:71-92.

Bebchuk, L. A., and J. Fried. 2004. Pay without Performance. Cambridge, MA: Harvard University Press.

Bebchuk, L. A., and Y. Grinstein. 2005. The Growth of Executive Pay. Oxford Review of Economic Policy 21:283-303.

Bebchuk, L. A., Y. Grinstein, and U. Peyer. Lucky CEOs and Lucky Directors. Journal of Finance, forthcoming.

Bebchuk, L. A., and A. Hamdani. 2002. Vigorous Race or Leisurely Walk? Yale Law Journal 112:553-615.

Bebchuk, L. A., and A. Hamdani. 2009. The Elusive Quest for Global Governance Standards. University of Pennsylvania Law Review 157:1263-317.

Bebchuk, L. A., R. Kraakman, and G. Triantis. 2000. Stock Pyramids, Cross-Ownership, and Dual Class Equity. In: R. Morck (eds.), Concentrated Corporate Ownership. Chicago, IL: University of Chicago Press.

Bebchuk, L. A., and Z. Neeman. 2009. Investor Protection and Interest Group Politics. Review of Financial Studies, this issue.

Bebchuk, L. A., and M. Roe. 1999. A Theory of Path Dependence in Corporate Ownership and Governance. Stanford Law Review 52:127-70.

Becht, M., and A. Röell. 1999. Blockholding in Europe: An International Comparison. European Economic Review 43:1049-56. 
Becht, M., P. Bolton, and A. Röell. 2003. Corporate Governance and Control. In George M. Constantinides, Milton Harris, and René M. Stulz (eds.), Handbook of the Economics of Finance, Amsterdam: North Holland.

Becht, M., J. Franks, C. Mayer, and S. Rossi. 2009. Returns to Shareholder Activism: Evidence from a Clinical Study of the Hermes U.K. Focus Fund. Review of Financial Studies, this issue.

Berle, A. A., and G. C. Means. 1932. The Modern Corporation and Private Property. New York, NY: MacMillan.

Bertrand, M., P. Mehta, and S. Mullainathan. 2002. Ferreting Out Tunneling: An Application To Indian Business Groups. The Quarterly Journal of Economics 117:121-48.

Bertrand, M., and S. Mullainathan. 2001. Are CEOs Rewarded for Luck? The Ones Without Principals Are. The Quarterly Journal of Economics 116:901-32.

Bhagat, S., and B. S. Black. 1999. The Uncertain Relationship between Board Composition and Firm Performance. The Business Lawyer 54:921-63.

Bhagat, S., and B. S. Black. 2002. The Non-Correlation between Board Independence and Longterm Firm Performance. Journal of Corporation Law 27:231-73.

Bizjak, J. M., R. Whitby, and M. Lemmon. 2009. Option Backdating and Board Interlocks. Review of Financial Studies 22:4821-47.

Borokhovich, K. A., K. R. Brunarski, and R. Parrino. 1997. CEO Contracting and AntiTakeover Amendments. Journal of Finance 52:1495-517.

Brav, A., W. Jiang, R. S. Thomas, and F. Partnoy. 2008. Hedge Fund Activism, Corporate Governance, and Firm Performance. Journal of Finance 63:1729-75.

Brickley, J. A., J. L. Coles, and R. L. Terry. 1994. Outside Directors and the Adoption of Poison Pills. Journal of Financial Economics 35:371-90.

Bruno, V., and S. Claessens. 2007. Corporate Governance and Regulation: Can There Be Too Much of a Good Thing? ECGI Working Paper Series in Finance 142.

Byrd, J. W., and K. A. Hickman. 1992. Do Outside Directors Monitor Managers? Evidence from Tender Offer Bids. Journal of Financial Economics 32:195-221. 
Carleton, W. T., J. M. Nelson, and M. S. Weisbach. 1998. The Influence of Institutions on Corporate Governance through Private Negotiations: Evidence from TIAA-CREF. Journal of Finance 53:1335-62.

Chhaochharia, V., and Y. Grinstein. 2006. Corporate Governance and Firm Value: The Impact of the 2002 Governance Rules. Journal of Finance 62:1789-825.

Chhaochharia, V., and Y. Grinstein. 2008. Executive Compensation and Board Structure. Working Paper, Cornell University.

Chhaochharia, V., and L. Laeven. 2007. The Invisible Hand in Corporate Governance. CEPR Discussion Paper 6256.

Claessens, S., S. Djankov, and L. H. P. Lang. 2000. The Separation of Ownership and Control in East Asian Corporations. Journal of Financial Economics 58:81-112.

Claessens, S., and L. Laeven. 2003. Financial Development, Property Rights and Growth. Journal of Finance 58:2401-36.

Coffee, J. 1999. The Future as History: The Prospects for Global Convergence in Corporate Governance and its implications. Northwestern Law Review 93:641-708.

Core, J., W. R. Guay, and D. F. Larcker. 2003. Executive Equity Compensation and Incentives: A Survey. Economic Policy Review 9:27-50.

Core, J., R. W. Holthausen, D. F. Larcker. 1999. Corporate Governance, CEO Compensation, and Firm Performance. Journal of Financial Economics 51:371-406.

Cotter, J. F., A. Shivdasani, and M. Zenner. 1997. Do Independent Directors Enhance Target Shareholder Wealth During Tender Offers? Journal of Financial Economics 43:195-218.

Cremers, M., and Y. Grinstein. 2009. The Market for CEO Talent: Implications for CEO Compensation. Yale ICF Working Paper 09-11.

Cyert, R. M., S.-H. Kang, and P. Kumar. 2002. Corporate Governance, Takeovers, and TopManagement Compensation: Theory and Evidence. Management Science 48:435-69. 
Daines, R. M. 2001. Does Delaware Law Improve Firm Value? Journal of Financial Economics 62:525-58.

Dann, L., D. Del Guercio, and M. Partch. 2003. Governance and Boards of Directors in Closedend Investment Companies. Journal of Financial Economics 69:111-48.

Dechow, P. M., R. G. Sloan, and A. P. Sweeney. 1996. Causes and Consequences of Earnings Manipulation: An Analysis of Firms Subject to Enforcement Actions by the SEC. Contemporary Accounting Research 13:1-21.

Del Guercio, D., and J. Hawkins. 1999. The Motivation and Impact of Pension Fund Activism. Journal of Financial Economics 52:293-340.

Dew-Becker, I., and R. J. Gordon. 2007. Selected Issues in the Rise of Income Inequality. Brookings Papers on Economic Activity 2:169-90.

Djankov, S., R. La Porta, F. Lopez-de-Silanes, and A. Shleifer. 2008. The Law and Economics of Self-Dealing. Journal of Financial Economics 88:430-65.

Doidge, C., G. A. Karolyi, K. V. Lins, R. M. Stulz, and D. P. Miller. 2009. Private Benefits of Control, Ownership, and the Cross-listing Decision. Journal of Finance 64:425-66.

Doidge, C., G. A. Karolyi, and R. M. Stulz. 2004. Why are Foreign Firms Listed in the U.S. Worth More? Journal of Financial Economics 71:205-38.

Edmans, A., X. Gabaix, and A. Landier. A Multiplicative Model of Optimal CEO Incentives in Market Equilibrium. Review of Financial Studies, forthcoming.

Faccio, M., and L. H.P. Lang. 2002. The Ultimate Ownership of Western European Corporations. Journal of Financial Economics 65:365-95.

Fahlenbrach, R., and R. M. Stulz. 2009. Bank CEO Incentives and the Credit Crisis. Charles A Dice Center Working Paper 2009-13.

Franks, J. R., and C. Mayer. 2001. Ownership and Control of German Corporations. Review of Financial Studies 14:943-77.

Frydman, C., and R. Saks. Executive Compensation: A New View from a Long-Term Perspective, 1936-2005. Review of Financial Studies, forthcoming. 
Gabaix, X., and A. Landier. 2008. Why Has CEO Pay Increased so Much? Quarterly Journal of Economics 123:49-100.

Gillan, S. L., and L. T. Starks. 2000. Corporate Governance Proposals and Shareholder Activism: The Role of Institutional Investors. Journal of Financial Economics 57:275-305.

Gillan, S. L., and L. T. Starks. 2007. The Evolution of Shareholder Activism in the United States. Journal of Applied Corporate Finance 19:55-73.

Gillette, A. B., T. H. Noe, and M. J. Rebello. 2003. Corporate Board Composition, Protocols, and Voting Behavior: Experimental Evidence. Journal of Finance 58:1997-2032.

Glaeser, E., and A. Shleifer. 2002. Legal Origins. Quarterly Journal of Economics 117:1193229.

Gompers, P. A., J. Ishii, and A. Metrick. 2003. Corporate Governance and Equity Prices. Quarterly Journal of Economics 118:107-155.

Gompers, P. A., J. Ishii, and A. Metrick. 2009. Extreme Governance: An Analysis of Dual-Class Firms in the United States. Review of Financial Studies, this issue.

Gordon, J. N. 2007. The Rise of Independent Directors in the United States, 1950-2005: Of Shareholder Value and Stock Market Prices. Stanford Law Review 59:1465-568.

Greenwood, R., and M. Schor. 2009. Investor Activism and Takeovers. Journal of Financial Economics 92:362-75.

Grossman, S., and O. Hart. 1980. Takeover Bids, the Free-Rider Problem, and the Theory of the Corporation. The Bell Journal of Economics 11:42-64.

Hail, L., and C. Leuz. 2006. International Differences in the Cost of Equity Capital: Do Legal Institutions and Securities Regulation Matter? Journal of Accounting Research 44:485-531.

Hallock, K. F. 1997. Reciprocally Interlocking Boards of Directors and Executive Compensation. Journal of Financial and Quantitative Analysis 32:331-44.

Hartzell, J. C., and L. T. Starks. 2003. Institutional Investors and Executive Compensation. Journal of Finance 58:2351-74. 
Hermalin, B. E. Corporate Governance: A Critical Assessment. In Robert Gibbons and John Roberts (eds.), Handbook of Organizational Economic. Princeton, NJ: Princeton University Press, forthcoming.

Hermalin, B. E., and M. S. Weisbach. 1991. The Effects of Board Composition and Direct Incentives on Firm Performance. Financial Management 20:101-12.

Hermalin, B. E., and M. S. Weisbach. 1998. Endogenously Chosen Boards of Directors and Their Monitoring of Management. American Economic Review 88:96-118.

Hermalin, B. E., and M. S. Weisbach. 2003. Boards of Directors as an Endogenously Determined Institution: A Survey of the Economic Literature. Economic Policy Review 9:7-26.

Hermalin, B. E., and M. S. Weisbach. 2009. Information Disclosure and Corporate Governance. Working Paper, Ohio State University.

Holderness, C. G. 2009. The Myth of Diffuse Ownership in the United States. Review of Financial Studies 22:1377-408.

Holmstrom, B. 1979. Moral Hazard and Observability. The Bell Journal of Economics 10:74-91.

Jackson, H. E., and M. J. Roe. 2008. Public Enforcement of Securities Laws: Resource-Based Evidence. Journal of Financial Economics 93:207-38.

Jensen, M., and K. Murphy. 1990. Performance Pay and Top-Management Incentives. Journal of Political Economy 98:225-64.

Jensen, M. C., K. J. Murphy, and E. Wruck. 2004. Remuneration: Where We've Been, How We Got to Here, What Are the Problems, and How to Fix Them. ECGI Working Paper Series in Finance 44.

Kahan, M. 2006. The Demand for Corporate Law: Statutory Flexibility, Judicial Quality, or Takeover Protection? The Journal of Law, Economics, and Organization 22:340-65.

Kahan, M., and E. Rock. 2007. Hedge Funds in Corporate Governance and Corporate Control. University of Pennsylvania Law Review 155:1021-93.

Kaplan, S. 2008. Are U.S. CEOs Overpaid? Academy of Management Perspectives 22:5-20. 
Kaplan, S. N., and J. Rauh. 2009. Wall Street and Main Street: What Contributes to the Rise in the Highest Incomes? Review of Financial Studies, this issue.

Karpoff, J. M. 2001. The Impact of Shareholder Activism on Target Companies: A Survey of Empirical Findings. Working Paper, University of Washington.

Karpoff, J. M., P. H. Malatesta, and R. A. Walkling. 1996. Corporate Governance and Shareholder Initiatives: Empirical Evidence. Journal of Financial Economics 42:365-95.

Kedia, S., and T. Philippon. 2009. The Economics of Fraudulent Accounting. Review of Financial Studies 22:2169-99.

Klein, A., and E. Zur. Hedge Fund Activism. Journal of Finance, forthcoming.

La Porta, R., F. Lopez-de-Silanes, and A. Shleifer. 1999. Corporate Ownership Around the World. Journal of Finance 54:471-517.

La Porta, R., F. Lopez-de-Silanes, and A. Shleifer. 2006. What Works in Securities Law? Journal of Finance 61:1-32.

La Porta, R., F. Lopez-de-Silanes, and A. Shleifer. 2008. The Economic Consequences of Legal Origin. Journal of Economic Literature 46:285-332.

La Porta, R., F. Lopez-de-Silanes, A. Shleifer, and R. W. Vishny. 1997. Legal Determinants of External Finance. Journal of Finance 52:1131-50.

La Porta, R., F. Lopez-de-Silanes, A. Shleifer, and R. W. Vishny. 1998. Law and Finance. Journal of Political Economy 107:1113-55.

La Porta, R., F. Lopez-de-Silanes, A. Shleifer, and R. W. Vishny. 2000a. Agency Problems and Dividend Policies Around the World. Journal of Finance 55:1-33.

La Porta, R., F. Lopez-de-Silanes, A. Shleifer, and R. W. Vishny. 2000b. Investor Protection and Corporate Governance. Journal of Financial Economics 58:3-27.

La Porta, R., F. Lopez-de-Silanes, A. Shleifer, and R. W. Vishny. 2002. Investor Protection and Corporate Valuation. Journal of Finance 57:1147-70. 
Leuz, C., K. V. Lins, and F. E. Warnock. 2009. Do Foreigners Invest Less in Poorly Governed Firms? Review of Financial Studies, this issue.

Levine, R. 2005. Law, Endowments, and Property Rights. Journal of Economic Perspectives, 19:61-88.

Lipton, M., and W. Savitt. 2007. The Many Myths of Lucian Bebchuk. Virginia Law Review 93:733-58.

Masulis, R. W., C. Wang, and F. Xie. 2007. Corporate Governance and Acquirer Returns. Journal of Finance 62:1851-89.

Morck, R., A. Shleifer, and R. W. Vishny. 1988. Management Ownership and Market Valuation: An Empirical Analysis. Journal of Financial Economics 20:293-315.

Morck, R., D. Wolfenzon, and B. Yeung. 2005. Corporate Governance, Economic Entrenchment and Growth. Journal of Economic Literature 43:657-722.

Murphy, K. J. 1999. Executive Compensation. In Orley Ashenfelter and David Card (eds.), Handbook of Labor Economics, Vol. 3. Amsterdam: North-Holland.

Murphy, K. J., and J. Zabojnik. 2007. Managerial Capital and the Market for CEOs. Working Paper, Queen's University.

Nenova, T. 2003. The Value of Corporate Votes and Control Benefits: A Cross-country Analysis. Journal of Financial Economics 68:325-51.

Pagano, M., A. Röell, and J. Zechner. 2002. The Geography of Equity Listing: Why do Companies List Abroad? Journal of Finance 57:2651-94.

Pagano, M., and P. Volpin. 2005a. The Political Economy of Corporate Governance. American Economic Review 95:1005-30.

Pagano, M., and P. Volpin. 2005b. Workers, Managers, and Corporate Control. Journal of Finance 60:841-68.

Perotti, E., and E.-L. von Thadden. 2006. The Political Economy of Corporate Control and Labor Rents. Journal of Political Economy 114:145-74. 
Perotti, E., and P. Volpin. 2008. Politics, Investor Protection and Competition. ECGI Working Paper Series in Finance 162.

Rajan, R., and L. Zingales. 2003. The Great Reversals: The Politics of Financial Development in the 20th Century. Journal of Financial Economics 69:5-50.

Rajan, R., and L. Zingales. 2004. Saving Capitalism from the Capitalists: Unleashing the Power of Financial Markets to Create Wealth and Spread Opportunity. Princeton, NJ: Princeton University Press.

Ravina, E., and P. Sapienza. 2009. What Do Independent Directors Know? Evidence from Their Trading. Review of Financial Studies, this issue.

Reese, W., and M. S. Weisbach. 2002. Protection of Minority Shareholder Interests, Crosslistings in the United States, and Subsequent Equity Offerings. Journal of Financial Economics 66:65-104.

Roe, M. 2003. Political Determinants of Corporate Governance. Oxford: Oxford University Press.

Romano, R. 1985. Law as a Product: Some Pieces of the Incorporation Puzzle. Journal of Law, Economics and Organization 1:225-67.

Romano, R. 1997. State Competition for Corporate Charters. In J. Ferejohn and B. Weingast (eds.), The New Federalism: Can the States be Trusted? Stanford, CA: Hoover Institution Press.

Shivdasani, A.1993. Board Composition, Ownership Structure and Hostile Takeovers. Journal of Accounting and Economics 16:167-98.

Shleifer, A., and R. Vishny. 1986. Large Shareholders and Corporate Control. Journal of Political Economy 94:461-88.

Shleifer, A., and R. Vishny. 1997. A Survey of Corporate Governance. Journal of Finance 52:737-83.

Siegel, J. 2005. Can Foreign Firms Bond Themselves Effectively by Renting U.S. Securities Laws? Journal of Financial Economics 75:319-59. 
Smith, A. 1776. An Inquiry into the Nature and Causes of the Wealth of Nations. Indianapolis, IN: Liberty Press.

Spamann, H. The 'Antidirector Rights Index' Revisited. Review of Financial Studies, forthcoming.

Stigler, G. 1971. The Theory of Economic Regulation. Bell Journal of Economic and Management Science 2:3-21.

Strine, L. E. Jr. 2006. Toward a True Corporate Republic: A Traditionalist Response to Bebchuk's Solution for Improving Corporate America. Harvard Law Review 119:1759-83.

Stulz, R. M. 1999. Globalization of Equity Markets and the Cost of Capital. Journal of Applied Corporate Finance 12:8-25.

Stulz, R. M., and R. Williamson. 2003. Culture, Openness, and Finance. Journal of Financial Economics 70:313-49.

Weisbach, M. S. 1988. Outside Directors and CEO Turnover. Journal of Financial Economics 20:431-60.

Zingales, L. 1994. The Value of the Voting Right: A Study of the Milan Stock Exchange Experience. Review of Financial Studies 7:125-48.

Zingales, L. 1995. What Determines the Value of Corporate Votes? Quarterly Journal of Economics 110:1047-73.

Zingales, L. 1998. Corporate Governance. In P. Newman (ed.), The New Palgrave Dictionary of Economics and the Law, New York, NY: MacMillan. 